\title{
ACCOUNTING COMPLIANCE: AN INSTITUTIONAL APPROACH TO ENSURE THE QUALITY OF ACCOUNTING INFORMATION OF THE ENTERPRISE
}

\author{
Svitlana Syrtseva', Yuliia Cheban²
}

\begin{abstract}
The subject of the study is theoretical, methodological and practical aspects of the formation, development and functioning of the accounting compliance system as an appropriate institution for ensuring the quality of enterprise accounting information. Methodology. The methodological basis of the study is general scientific and special methods of cognition. In the course of the study, the following methods were used: abstract-logical method was used for the cognition of the essence, approaches, clarification of the concept of "compliance", "accounting compliance"; bibliographic method was used for the study and development of scientific works devoted to the definition of the essence of the term "compliance"; graphic method was used for the design of the described processes using logical block diagrams; system-structural analysis was used to improve the mechanism for the formation and implementation of the accounting compliance system as an institution for ensuring the quality of accounting information. The objective of the study is to consider the essence of the concept of "compliance", "accounting compliance", to establish and define the role of accounting compliance in ensuring the quality of accounting information, to substantiate methodological approaches and practical recommendations for its formation and implementation at the enterprise. Results. The study has established that the definition of "compliance" should include an institutional approach, i.e. "compliance" should be understood as an institution of the internal control and corporate ideology system, which, using a system of regulations and a set of control mechanisms, forms the company's ability to comply with established norms, standards, rules and procedures; a means of propaganda aimed at promoting the requirements for compliance with internal regulatory documents and generally accepted social values of the enterprise; a set of measures aimed at identifying risks accompanying the activities of the enterprise and eliminating their adverse consequences. "Accounting Compliance" is an institution of the internal control and corporate ideology system of the enterprise, which with the help of a system of measures and a set of control mechanisms provides the ability to track, monitor, evaluate and comply with the requirements of regulatory documents, regulations, instructions in the accounting system. It must be necessarily aimed at identifying, reducing and eliminating the risks of distortion, misrepresentation and falsification of accounting information. It has been substantiated that the accounting compliance system, as an appropriate institution, should be formed in stages, based on a set of specially developed internal methods, rules and procedures. It has been proved that most of the actions of the compliance system are aimed at identifying, analysing and assessing risks in the accounting system, and a significant number of documents defining its normative content are closely related to the implementation of the risk management function. Practical implications. In order to ensure the identification of compliance risks in the company's accounting system and determine their impact on the formation and quality of accounting information, the grouping of risks by type is presented. To implement the functions of accounting compliance, it was proposed to develop and approve a number of internal standards and regulations, which will guide the employees of the Compliance Department in their work. In order to ensure the quality of accounting information to users necessary for making effective management decisions, the organizational and economic mechanism of the accounting compliance system has been developed. Conclusion of the study. Thus, accounting compliance, as an institution for ensuring the quality of accounting information at an enterprise, should be focused on finding, identifying,
\end{abstract}

\footnotetext{
Corresponding author:

${ }^{1}$ Mykolayiv National Agrarian University, Ukraine.

E-mail: sirceva@mnau.edu.ua

ORCID: https://orcid.org/0000-0003-4824-3741

ResearcherID: D-2950-2018

${ }^{2}$ Mykolayiv National Agrarian University, Ukraine.

E-mail: heban@mnau.edu.ua

ORCID: https://orcid.org/0000-0002-8231-2918

ResearcherID: D-2907-2018
} 
Vol. 7 No. 2, 2021

assessing, analysing and taking measures to minimize compliance risks in the accounting system arising from noncompliance with established rules, standards and procedures for organization and maintenance of accounting. Substantiated methodological foundations and recommendations for the formation and implementation of accounting compliance will not only ensure the quality of accounting information, but also guarantee business purity, a high level of corporate culture. The latter will contribute to improving the efficiency of economic activities and sustainable development of the enterprise.

Key words: compliance, accounting compliance, accounting information, quality of accounting information, financial statements, compliance risks.

JEL Classification: D73, M40, M41, M49

\section{Introduction}

Under the conditions of the institutional environment, the traditional view and attitude towards such a subsystem of enterprise management as accounting is changing. The main task of accounting is to provide complete and reliable information to all users of the enterprise for making rational management decisions. As a specific system, the following features are inherent in it: fullness, hierarchy, integrity, purposefulness, reliability, level of independence and openness, complexity. In the institutional economy, in addition to the generally accepted functions, accounting performs the following ones: formation of information about the entrepreneurial ability of management; informing the owner about the condition of the property over which he or she does not have direct control; formation of an information base for making decisions on investing funds; formation of archives (history of the enterprise); evidentiary instrument in courts (Chyzhevska, 2013). Transnationalization processes in the economy and the integration of Ukraine into the world economic community have a direct impact on the development of national accounting and require effective implementation of international financial reporting standards into accounting practice. The requirements for the quality of accounting information that must be presented in the financial statements of the enterprise are also increasing.

Thus, the information in accounting must be of high quality in order to ensure the reliability, comparability, clarity and truthfulness of the reflection of the facts of the economic activity of the enterprise. On the other hand, inaccurate information about the financial condition and performance of business entities makes it impossible to make reasonable management decisions and, as a result, leads to economic losses, investor distrust and sanctions from regulatory authorities. However, in some cases, it can be difficult to identify and avoid possible misstatements, errors and fraud in the financial statements, since fraud sometimes appears to be lawful transactions committed in accordance with applicable law. In this regard, the issue of ensuring and improving the quality of accounting information with the help of appropriate tools, among which there should be accounting compliance, is relevant.

\section{The essence of the concept of "compliance" and "accounting compliance"}

Compliance was first applied at the beginning of the 20th century in the United States, when the Food and Drug Administration was created to develop and implement the rules for the functioning of business participants in the pharmaceutical and food industries. A prerequisite for the development of compliance was the adoption of Foreign Corrupt Practices Act of 1977 by the USA, which introduced requirements for accounting and financial documentation, and established rules for controlling relations with state authorities.

Today in the modern economic literature there is no single approach to the definition of the concept of "compliance". Table 1 shows the results of summarizing the most common approaches.

The analysis of the definitions presented in Table 1 made it possible to conclude that the definition of the term "compliance" was carried out through such concepts as an integrated programme, management, function, control, guarantee of protection of reputation and elimination of reputational risks, which did not fully disclose its content.

In our opinion, the definition of "compliance" should include an institutional approach. Indeed, in the general sense, an institution is a set of customs, procedures, norms, rules of behaviour operating in society, as well as a set of mechanisms that control and support their implementation.

Thus, "compliance" is:

- the internal control and corporate ideology system, which, with the help of a system of regulations and a set of control mechanisms, forms the company's ability to comply with established norms, standards, rules, and procedures;

- a means of propaganda aimed at promoting requirements for compliance with internal regulatory 
Table 1

Modern approaches to the definition of "compliance"

\begin{tabular}{|c|c|c|}
\hline Approach & Source & Definition \\
\hline \multirow{2}{*}{ 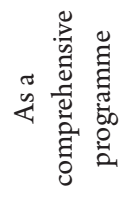 } & Valiev, 2015 & $\begin{array}{l}\text { Compliance is a set of real measures aimed at protecting businesses from corruption both externally } \\
\text { and in the enterprise. }\end{array}$ \\
\hline & Kobielieva, 2018 & $\begin{array}{l}\text { Compliance is a set of regulations that shapes the company's ability to comply with applicable laws, } \\
\text { instructions, rules and regulations. }\end{array}$ \\
\hline \multirow{3}{*}{ 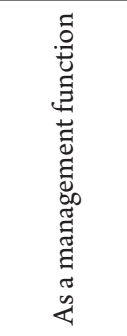 } & Nieizviestna, 2017 & $\begin{array}{l}\text { Compliance is a set of functions built into the organization's business process aimed at adherence to } \\
\text { internal business standards, corporate ethics, legal and regulatory requirements in order to achieve } \\
\text { the highest efficiency }\end{array}$ \\
\hline & Ambrozhevich, 2011 & $\begin{array}{l}\text { Compliance is a function with the purpose to manage compliance risks and maintain an adequate } \\
\text { compliance culture in the company. }\end{array}$ \\
\hline & $\begin{array}{l}\text { Krepysheva, } \\
\text { Sergievskaya \& } \\
\text { Storchevoy, } 2020\end{array}$ & $\begin{array}{l}\text { Compliance is an important management function of the company, in particular Risk Management, } \\
\text { aimed at identifying ways to prevent them }\end{array}$ \\
\hline \multirow{2}{*}{ 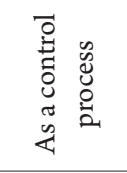 } & Chekh et al., 2019 & $\begin{array}{l}\text { Compliance is a process of control at the enterprise over the observance of regulatory legal acts and } \\
\text { prevention of compliance risks }\end{array}$ \\
\hline & $\begin{array}{l}\text { Ermakova \& Akhmetova, } \\
2014\end{array}$ & $\begin{array}{l}\text { Compliance is a process that is carried out by management bodies and employees of an organization } \\
\text { in order to control compliance with applicable laws, rules, and standards, both internal and external. }\end{array}$ \\
\hline \multirow{3}{*}{ 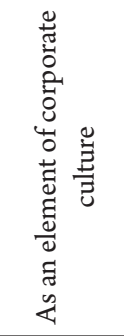 } & Covali, 2019 & $\begin{array}{l}\text { Compliance is a guarantee of reputation protection, since monitoring and control of an enterprise's } \\
\text { reputational risks is usually assigned to compliance and is perceived in the international financial } \\
\text { compliance sphere as a compliance institution formed long ago }\end{array}$ \\
\hline & Palcun, 2013 & $\begin{array}{l}\text { Compliance is a corporate policy aimed at minimizing legal and reputational risks arising from the } \\
\text { employees violating professional and ethical requirements established by the company's documents }\end{array}$ \\
\hline & Bondarenko, 2008 & $\begin{array}{l}\text { Compliance is an integral part of the company's corporate culture, in which the performance of } \\
\text { their job responsibilities, including decision-making at all levels, by each employee must comply } \\
\text { with the standards of legality and integrity }\end{array}$ \\
\hline \multirow{3}{*}{ 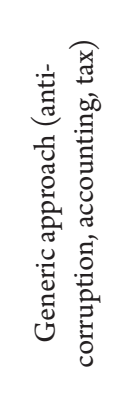 } & Kobielieva, 2019 & $\begin{array}{l}\text { Antimonopoly compliance is a set of legal and organizational measures provided for by an internal } \\
\text { act (acts) of an economic entity or another person from the persons belonging to the same group } \\
\text { of persons with such an economic entity, if such internal acts apply to the relevant economic entity } \\
\text { and are aimed at complying with the requirements of antimonopoly legislation }\end{array}$ \\
\hline & Miheev, 2013 & $\begin{array}{l}\text { Accounting compliance is a process of managing the risks of misstatement of financial statements } \\
\text { due to conflicts of professional judgment in the application of the provisions of accounting } \\
\text { regulations }\end{array}$ \\
\hline & Korostelkin, 2014 & $\begin{array}{l}\text { Tax compliance ensures compliance with tax legislation by participants in tax legal relations and } \\
\text { provides, first of all, minimization of financial, economic, legal and tax expenses arising from } \\
\text { violations of tax legislation }\end{array}$ \\
\hline
\end{tabular}

documents and generally accepted social values of the enterprise;

- a set of measures aimed at identifying risks accompanying the activities of the enterprise and eliminating their adverse consequences.

"Accounting compliance", in our opinion, is an institution of the internal control and corporate ideology system of the enterprise, which provides the ability to track, monitor, evaluate and comply with the requirements of regulatory documents, regulations, instructions in the accounting system with the help of a system of measures and a set of control mechanisms. Accounting compliance is necessarily aimed at identifying, reducing and eliminating the risks of distortion, misrepresentation and falsification of accounting information.

\section{Compliance in the system of ensuring the quality of accounting information}

According to the Reporting Survey 2011 conducted by the audit firm PricewaterhouseCoopers, $65 \%$ of CEOs surveyed noted that the top priority in reporting is the quality of the information provided in it. High requirements for the quality of accounting information are the result of the growing importance of the public image of companies and constant monitoring of their development by investors. In addition, $85 \%$ of enterprises planned to take further measures and apply tools aimed at improving the quality of accounting information.

The quality of accounting information correlates with the effectiveness of the implementation of the entire management process: the higher the quality parameters 
of information, the better the ability of managers to prepare optimal decisions. At the same time, the presence of inaccuracies and errors in the reporting, as well as the desire of management personnel to hide the reliable data of the reports in order to present the financial position of the enterprise in a more attractive light for investors, misleads the users of accounting information and reduces the confidence of stakeholders in the management of the enterprise (Pravdiuk N. \& Pravdiuk M., 2016).

Therefore, today, in order to avoid problems with the preparation of high-quality accounting information, most enterprises need to introduce such an effective tool as accounting compliance.

The formation of an accounting compliance system and its implementation at the enterprise is a step-bystep process, shown in Figure 1.

The implementation of the accounting compliance system must begin with the formation of the company's compliance policy. Compliance policy is a set of means, methods and procedures aimed at managing compliance risks.

The purpose of the compliance policy is to minimize or eliminate compliance risks, primarily those that can significantly affect the quality of accounting information in financial statements. It can manifest itself in the form of applying various sanctions, financial or reputational losses as a result of noncompliance with laws, rules and standards (Kobielieva, 2019).

For the effective functioning of the accounting compliance system at the enterprise, firstly, it is necessary to develop and approve a number of internal standards and regulations, which will guide the employees of the Compliance Department in their work.

Such documents should be:

1. Code of corporate ethics (conduct) of the enterprise. This is a general document that regulates the norms of behaviour of employees of the enterprise when interacting with counterparties (customers, suppliers), supervisory authorities and other third parties with whom this or that employee deals in the course of performing his or her professional duties.

2. Regulations on the organization of accounting compliance at the enterprise. This is a generalizing document that defines the procedure for the creation and operation of an accounting compliance system. It has to reveal: the purpose and organizational order of functioning at the enterprise; job duties of employees and basic requirements for their performance; descriptions of methodological approaches, techniques, rules, procedures and requirements, the implementation of which ensures the objective and reliable nature of the results and conclusions of accounting compliance; algorithms of actions for the main procedures, criteria for assessing risk, a list of indicators and articles that must be considered and analysed without fail; the procedure for preparing and submitting information to the company's management based on the results of accounting compliance; reactions in case of identifying deviations and violations during accounting compliance.

3. Job descriptions of employees of the Compliance Department. They determine the uniform principles

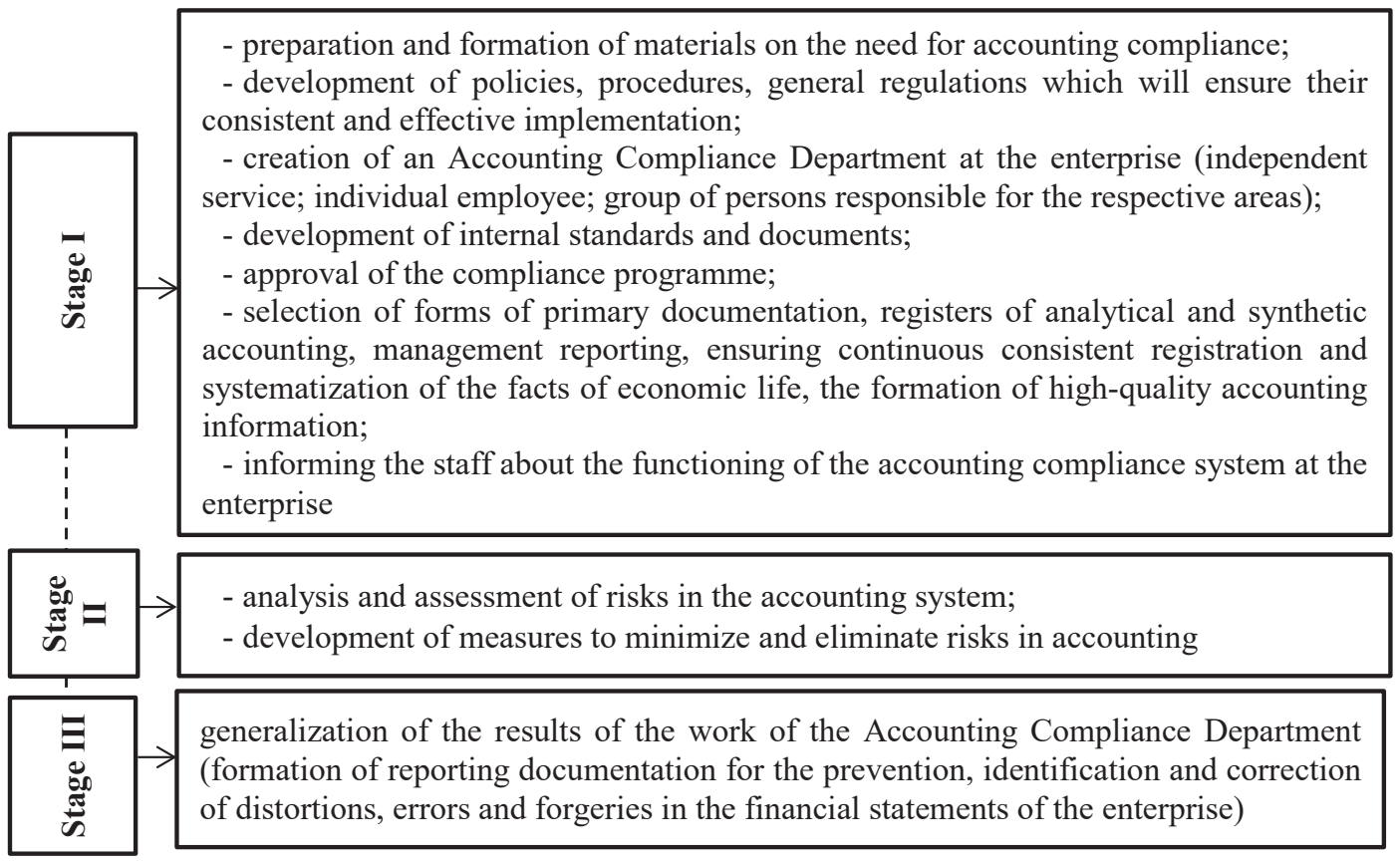

Figure 1. Stages of formation and implementation of the accounting compliance system at the enterprise Source: prepared by the authors 
of activity, the scope of job duties and the basic requirements for their performance, rights and scope of responsibility.

4. Accounting compliance procedure. This is a document that contains detailed algorithms for the actions of compliance controllers, the distribution of responsibility for the order and timing of control procedures.

5. The procedure for registering the results of accounting compliance. This is a document that discloses the basic requirements for the preparation and presentation of information to the company's management based on the results of accounting compliance. It may contain developed and approved forms of reporting documentation.

The methodological support of accounting compliance is based on the relevant working documentation, the development of which presupposes a certain level of formalization, including organizational consolidation and structuring of all control actions and procedures. Such documents can be developed in any form. However, at the enterprise it is desirable to approve a detailed description of the set of documents and accounting registers, which will guide the employees of the Compliance Department in their work.

\section{Methodology for identification, assessment and analysis of compliance risks}

One of the main objectives of the compliance policy is the identification, assessment and analysis of compliance risks. In order to identify compliance risks, it is necessary to have information about the types of risks in the accounting system, the causes and factors of their occurrence, the methods of identification and the nature of the impact on the final indicators of the company's financial statements.

We support the position of B.A. Zasadnyi (Zasadnyi, 2017) that one of the biggest risks of the accounting system in the context of applying IFRS is the poor quality of information reflected in the financial statements.

To increase the identification of risks in the company's accounting system, risks are grouped by type (Table 2).

Regarding the factors affecting the degree of risk in accounting, they can be conditionally divided into two groups:

1. Objective. They do not directly depend on the decision-making subject. These are inflation, competition, political and economic crises, ecology, behaviour of suppliers and buyers, changes in the taxation system, etc.

2. Subjective. They directly characterize the employees of the Accounting Department: the level of competence and intellectual potential of the accountant, the level of awareness in the field of economic, civil and labour legislation, organization of accounting at the enterprise, etc. (Vyhivska, 2006).

It is possible to identify the risks of influencing the quality of the company's accounting information by analysing the accumulated information for past reporting periods, in which there have been cases of theft and damage to property, incorrect assessment of accounting objects, errors in financial statements, overstating the company's expenses, concealing income, etc.

The compliance risk assessment process should include risk identification methods, mechanisms for controlling business processes and control procedures that are designed to comply with legal requirements in accordance with the industry sector of the enterprise.

Compliance risk assessment should be carried out taking into account: professional competence of employees of department performing compliance control functions; the scale and types of activities of the organization; customer base (in the context of suppliers, buyers and other counterparties); the presence of structural units, including those in other regions; establishment of legislative and regulatory acts in the field of accounting and taxation (Kevorkova \& Sapozhnikova, 2020).

To identify and assess the risks, we propose to draw up such special documents as:

1. The risk map is a document that, as a rule, is drawn up in a tabular form, which indicates risk factors, the likelihood of a negative event, possible losses/damages, and ways to prevent risk. Drawing up such a document will allow to get an idea of the company's activities in the shortest possible time. It can serve as a basis for checking the effectiveness of control procedures and assessing the risk of material misstatement of the accounting (financial) statements.

2. The risk assessment ranking table. For example, there can be proposed a methodology for ranking risk by probability, based on the likelihood of the risk occurring during the reporting period. It is a little more difficult to offer options for ranking by consequences.

3. The risk matrix is an informative document that can be used to obtain a risk assessment. Each cell of the matrix reflects the assessment of each risk (depending on the established criteria).

On the identified compliance risks, the compliance officers should take actions to indicate material misstatements, distortions and misrepresentation of information in the financial statements and certainly inform the management of the enterprise and its owners about this. The choice of actions and activities of compliance officers should be based on their professional judgment.

In order to avoid or minimize compliance risks in the accounting system at the enterprise, we propose to introduce and use the following measures to 
Vol. 7 No. 2, 2021

Table 2

Risk groups and their impact on the formation and quality of accounting information

\begin{tabular}{|c|c|c|}
\hline Risk group & Types of risks & $\begin{array}{l}\text { Impact of risk on the } \\
\text { formation and quality of } \\
\text { accounting information }\end{array}$ \\
\hline \multirow{3}{*}{ 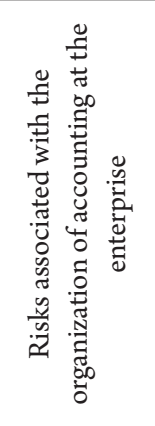 } & $\begin{array}{l}\text { The risk of the formation of the Order on accounting policy is associated with errors and vague } \\
\text { wording of the provisions of the Order, which have a double interpretation of the same } \\
\text { position and create the basis for choosing the accounting method, and not strict adherence } \\
\text { to certain provisions }\end{array}$ & \multirow{3}{*}{$\begin{array}{l}\text { Lead to distortion and } \\
\text { incomplete accounting } \\
\text { information }\end{array}$} \\
\hline & $\begin{array}{l}\text { The risk of choosing the form of organization and accounting records maintenance can cause } \\
\text { additional costs, an increase in the degree of information risk and the risk of liability to users } \\
\text { of financial statements }\end{array}$ & \\
\hline & $\begin{array}{l}\text { The risk of the formation and presentation of financial statements consists in non-compliance } \\
\text { with the requirements of the legislation on the disclosure of reliable information in the } \\
\text { statements; may be associated with data manipulation and distortion of information } \\
\text { provided to users }\end{array}$ & \\
\hline \multirow{4}{*}{ 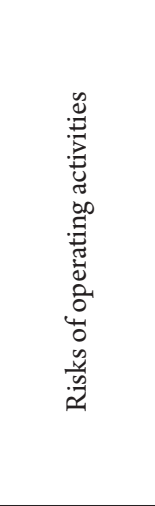 } & $\begin{array}{l}\text { Production risk consists in an increase in the costs of the enterprise due to unjustified cost } \\
\text { overruns. }\end{array}$ & $\begin{array}{l}\text { Decrease in capital. } \\
\text { Impact on the indicator - } \\
\text { production costs }\end{array}$ \\
\hline & $\begin{array}{l}\text { Commercial risk consists in the increase in the company's expenses associated with losses } \\
\text { from damage to products in warehouses and during transportation; payment of fines, } \\
\text { penalties, forfeit for violation of the terms of contracts }\end{array}$ & $\begin{array}{l}\text { Decrease in capital. Impact } \\
\text { on the indicator - marketing } \\
\text { costs }\end{array}$ \\
\hline & $\begin{array}{l}\text { Property risk consists in the decrease in the value of the enterprise's property associated with } \\
\text { theft and deficiencies, losses exceeding the rate of natural loss }\end{array}$ & $\begin{array}{l}\text { Decrease in capital. Impact } \\
\text { on the indicator - operating } \\
\text { activity expenses }\end{array}$ \\
\hline & $\begin{array}{l}\text { The risk of emergency activities consists in the occurrence of unpredictable situations, } \\
\text { accompanied by the loss of enterprise assets, additional costs for eliminating the } \\
\text { consequences of emergency situations; costs of compensation for damage to the } \\
\text { environment }\end{array}$ & $\begin{array}{l}\text { Decrease in capital. } \\
\text { Impact on the indicator - } \\
\text { extraordinary expenses }\end{array}$ \\
\hline \multirow{2}{*}{ 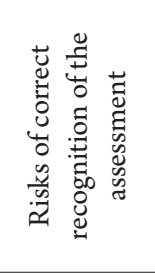 } & $\begin{array}{l}\text { The risk of change in the value of assets is manifested through methods of further assessment } \\
\text { (revaluation) of assets. For fixed assets, the result of revaluation is the adjustment of their } \\
\text { initial cost and the amount of accrued depreciation. For inventories, it manifests itself } \\
\text { through the choice of methods for assessing inventory write-off in the event that this } \\
\text { method does not meet the requirements of the market environment }\end{array}$ & \multirow[t]{2}{*}{$\begin{array}{l}\text { Increase or decrease in } \\
\text { capital. Growth in other } \\
\text { operating activity expenses }\end{array}$} \\
\hline & $\begin{array}{l}\text { Credit risk manifests itself through the growth of bad and doubtful accounts receivable as } \\
\text { part of the initial cost of accounts receivable, not confirmed by a reserve of doubtful debts }\end{array}$ & \\
\hline \multirow{2}{*}{ 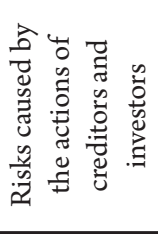 } & $\begin{array}{l}\text { The risk of the procurement process lies in the fact that the company may have to pay fines, } \\
\text { penalties and forfeitures in case of late or incomplete repayment of obligations to suppliers } \\
\text { and other creditors }\end{array}$ & \multirow{2}{*}{$\begin{array}{l}\text { Decrease in capital. Impact } \\
\text { on the indicator of other } \\
\text { operating activity expenses }\end{array}$} \\
\hline & $\begin{array}{l}\text { Interest rate risk is caused by possible changes in interest rates on loans and borrowings, as } \\
\text { well as the need to pay additional amounts in case of untimely or incomplete repayment of } \\
\text { loans }\end{array}$ & \\
\hline
\end{tabular}

Source: performed by the authors based on materials (Hnylytska, 2017, Vyhivska, 2010)

be implemented as part of ensuring the quality of accounting information: increase the volume of substantive procedures related to the detection of errors in accounting and reporting; increase the sample size when performing compliance testing; make changes in the timing of the implementation of the procedures provided for by the compliance system; involvement of other specialists or experts (legal advice, auditors, forensic specialists).

\section{Organizational and economic mechanism of accounting compliance}

Disclosure of the theoretical essence of accounting compliance provides for the definition of functions, policies and principles in this direction of the economic activity of the enterprise.

The objectives of accounting compliance determine the assessment of the compliance of the application of accounting procedures and accounting policies in accordance with the established requirements; identification, assessment and prevention of risks of misrepresentation of accounting information.

It should be noted that ensuring accounting compliance at the enterprise should be carried out with a known level of formalization, which provides for the organizational consolidation and putting in order all control actions and procedures.

The theoretical essence of accounting compliance as an economic category, its place in ensuring the quality 
Accounting compliance as an institution for ensuring the quality of accounting information

Goal: ensuring the level of reliability of accounting information in accordance with the established legislation

Objectives: assessment of the compliance of the application of accounting procedures and accounting policies in accordance with the established requirements; identification, assessment and prevention of risks of distortion of information in financial statements; prevention of errors and deliberate distortions in the enterprise accounting data

Object: presented accounting data and forms of financial statements of the enterprise.

Subject: violation of accounting records maintenance rules, the procedure for the formation and presentation of financial statements

Principles: responsibility, independence, availability of resources, inevitability of punishment

Methodological and technological support of accounting compliance

$\rightarrow$ Accounting compliance functions: protective, regulatory, preventive, informational.

Threat detection tools: compliance monitoring; compliance diagnostics and control; risk management; interaction with other control services.

Accounting compliance methods and procedures: accounting data research methods and procedures; statistical methods of analysis; audit methods; forensic accounting methods and procedures

\section{Organizational support of accounting compliance:}

- formation of a compliance management system;

- justification for the creation of a Compliance Department (independent service; individual employee; group of persons responsible for the relevant areas);

- development of internal standards and documents;

- development and implementation of a compliance programme, plans, strategy;

- development of a system for assessing and monitoring compliance risks in accounting.

Expected result:
$\rightarrow$
- prevent, reduce the risk of distortion and misrepresentation of financial statements;
- increasing the responsibility of employees of the enterprise, in particular the accounting
service;
- increasing the reputation of the company;
- increasing the investment attractiveness of the enterprise.

Figure 2. Organizational and economic mechanism of accounting compliance

Source: performed by authors

of accounting information and organizational and economic mechanism are presented in Figure 2.

The proposed organizational and economic mechanism of the accounting compliance system will help ensure the quality of accounting information necessary for both internal and external users in order to make effective management decisions. The result of such decisions is the effective operation of the enterprise, attracting investment, etc.

\section{Conclusions}

Thus, accounting compliance, as an appropriate institution for the quality of accounting information at an enterprise, should be focused on finding, identifying, assessing, analysing and taking measures to minimize compliance risks in the accounting system arising from non-compliance with established rules, standards and organizational procedures for the organization and maintenance of accounting.

For the formation of an accounting compliance system and its implementation at the enterprise, it is advisable to use a certain algorithm, which includes the following stages: implementation of the compliance system, risk monitoring, generalization of results.

The necessary accounting support for accounting compliance can be built on the basis of an appropriate system of internal standards and regulatory documents, which will guide the employees of the compliance service in their work. These are general purpose documents and regulations for conducting accounting compliance.

The effectiveness of accounting compliance depends on properly organized and well-regulated work with compliance risks. To identify and assess risks, it has been proposed to draw up such special 
documents as a risk map, a risk assessment ranking table, a risk matrix.

Prevention or minimization of compliance risks in the accounting system at an enterprise is possible by introducing the following measures to be implemented as part of ensuring the quality of accounting information: increasing the volume of procedures in essence related to the detection of errors in accounting and reporting; increasing the sample size in the implementation of compliance testing; amending the timing of the procedures provided for by the compliance system; involvement of other specialists or experts (legal advice, auditors, forensic specialists).
The proposed organizational and economic mechanism is the basic platform of the accounting compliance system at the enterprise, capable of ensuring the quality of accounting information necessary for both internal and external users in order to make effective management decisions.

Substantiated methodological principles and recommendations for the formation and implementation of accounting compliance will not only ensure the quality of accounting information, but also the guarantee of business purity, a high level of corporate culture, which will improve the efficiency of economic activities and sustainable development of the enterprise.

\section{References:}

Ambrozhevich, O. (2011). Komplaens: s nim ili bez nego [Compliance. With or without it]. Bulletin of NAUFOR, no. 9, pp. 54-60.

Bondarenko, Y. (2008). Effektivnoe upravlenie komplaens-riskami: sistemnyi podkhod i kriticheskii analiz [Effective management of joint-risk: a systematic approach and critical analysis]. Corporate lawyer, no. 6, pp. 29-32. Chekh, N., Panov, V., Shpilko, V., \& Savenko, K. (2019). The concept of regulatory compliance: the meaning and place in the economic security system of the enterprise (example of water supply and supply). Innovative Technologies and Scientific Solutions for Industries, no. 3(9), pp. 53-61. doi: 10.30837/2522-9818.2019.9.053

Chyzhevska, L. (2013). Yakist oblikovoi informatsii pro hroshovi koshty, rozrakhunky i kontrol za neiu [The quality of accounting information on funds, settlements and control over it]. Culture of the peoples of the Black Sea region, no. 258, pp. 96-99.

Ermakova, N. A., \& Akhmetova, Ch. F. (2014). Komplaens-kontrol v sisteme vnutrennego kontrolia korporatcii [Compliance - control system of internal control of corporations]. International Accounting, vol. 17, iss. 3, pp. 2-10. Hnylytska, L. V. (2017). Oblikovo-analitychne zabezpechennia ekonomichnoi bezpeky pidpryiemstva. Kyiv: KNEU. (in Ukrainian)

Kevorkova, Zh. A., \& Sapozhnikova, N. G. (2020). Conceptual provisions of compliance as a form of internal control in economic entities. Accounting. Analusis. Auditing, no. 7(2), pp. 6-16. doi: 10.26794/2408-9303-2020-72-6-16

Kobielieva, T. O. (2018). Komplaiens yak katehoriia ekonomichnoi bezpeky promyslovoho pidpryiemstva [Compliance as a category of economic security of an industrial enterprise]. Economics: time realities. Scientific journal, no. 6(40), pp. 52-59.

Kobielieva, T. O. (2019). Komplaiens-bezpeka promyslovoho pidpryiemstva: teoriia ta metody. Kharkiv: OOO «Planeta-prynt» (in Ukrainian)

Korostelkin, M. M. (2014). Nalogovyi komplaens kak sistema podtverzhdeniia dostovernosti rascheta nalogovykh obiazatelstv [Tax compliance as a system for confirming the accuracy of calculating tax liabilities]. Management Accounting, no. 11, pp. 60-65.

KPMG International Survey of Corporate Responsibility Reporting, 2011. Available at: https://www.upj.de/ fileadmin/user_upload/MAIN-dateien/Aktuelles/Nachrichten/kpmg_reportingsurvey_2011.pdf

Krepysheva, A. M., Sergievskaya, A. A., \& Storchevoy, M. A. (2020). Definition and measurement of risk in compliance management. Strategic Decisions and Risk Management, no. 11(2), pp. 150-159. doi: 10.17747/2618947X-2020-2-150-159

Miheev, M. V. (2013). Bukhgalterskii komplaens kak metod predotvrashcheniia iskazhenii $\mathrm{v}$ bukhgalterskoi otchetnosti stroitelnykh organizatcii [Accounting compliance as a method of preventing distortions in the accounting statements of construction organizations]. Journal Audit and financial analysis, no. 2, pp. 69-72.

Nieizviestna, O. V. (2017). Doslidzhennia praktyky komplaiens u strakhovykh kompaniiakh Ukrainy [Research on the compliance practice in insurance companies of Ukraine]. Actual problems of economics, no. 3, pp. $267-273$.

Palcun, I. M. (2013). Compliance-polityka yak skladova korporatyvnoi kultury pidpryiemstva [Compliance policy as a component of corporate culture of the enterprise]. Trade and market of Ukraine: Collection of scientific works, no. 35, pp. 134-141.

Pravdiuk, N. L., \& Pravdiuk, M. V. (2016). Quality of Accounting Information: Essence and Assessment Method. Accounting and Finance, no. 2(72), pp. 57-64.

Valiev, V. Kh. (2015). Komplaens-funktciia v sovremennykh predpriiatiiakh pridorozhnogo servisa, kak odin iz effektivnykh etodov upravleniia riskami [The compliance function in modern enterprises roadside service as one of the most effective methods of risk management]. Modern problems of science and education, no. 2, part 2. Available at: https://www.science-education.ru/pdf/2015/2-2/27.pdf (accessed February 25, 2020). 
Vyhivska, I. M. (2006). Ryzyk v bukhhalterskomu obliku: problema traktuvannia [Risk in accounting: the problem treatment]. Bulletin of ZhSTU, no. 4(38), pp. 20-29.

Vyhivska, I. M. (2010). Sutnist i klasyfikatsiia profesiinykh ryzykiv oblikovoho personalu [Essence and classification of occupational risks of accounting staff]. Bulletin of ZhSTU, no. 4(54), pp. 40-43.

Zasadnyi, B. A. (2017). Ryzyky systemy bukhhalterskoho obliku v umovakh zastosuvannia MSFZ [Risks of the accounting system in the conditions of application of IFRS]. Scientific Bulletin of Uzhhorod University. Economics Series, issue 14, part 1, pp. 111-115.

Covali, O. (2019). Organizatciia, metodika, poniatie i sushchnost komplaens-kontrolia [Organization, methodology, concept and essence of compliance control]. In: Studia Universitatis Moldaviae (Seria Ştiințe Exacte şi Economice), no. 2(122), pp. 138-142. 